\title{
Biophysical Effect of EMR with 5GHz on Male Reproductive System of Mus musclus Mice
}

\author{
${ }^{*}$ Qusay K. Al-Dulamey **Abd-Alkareem H. Ismail *** Yasir A. Al-Jawwady \\ *Department of Biophysics/College of Sciencel University of Mosul \\ **Department of Biology/College of Education/University of Mosul \\ ***Department of Physics/ College of Sciencel University of Mosul
}

(Received 22 / 5/2018; Accepted 1/ 11/2018)

\begin{abstract}
To study the effect of microwave radiation with power density 100,150 and 200 microwatt / $\mathrm{cm}^{2}(\mu \mathrm{W} / \mathrm{cm} 2)$ of exposure on male reproductive system of Mus musclus Swiss albino mice. The results of the first group exposed to $100 \mu \mathrm{W} / \mathrm{cm}^{2}$ showed a significant decrease $(\mathrm{p}<0.05)$ in no. of sperm cells in epididymis percentage of living sperm cells and percentage of normal sperm cells respectively while a significant increase $(\mathrm{p}<0.05)$ in percentage of dead sperm cells and percentage of abnormal sperm cells was found. The second and third groups exposed to microwave radiation at 150 and $200 \mu \mathrm{W} / \mathrm{cm}^{2}$. The $5 \mathrm{GHz}$ on microwave radiation has a harmful effects physiologically and histopathologically for reproductive system. Exposure for long time to radiation from communication that have this same frequency as $\mathrm{WI}-\mathrm{Fi}$ or any communication from internet should be avoided.
\end{abstract}

Keywords: Sperm reproductive system, Necrosis testis, Testosterone ovary.

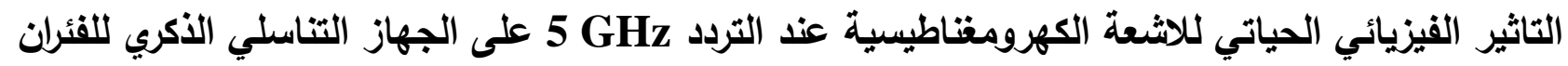

$$
\begin{aligned}
& \text { الملخص } \\
& \text { تمت دراسة تأثير موجات المايكرويف بكثافة قدرة } 100 \text { ، } 150 \text { و } 200 \text { مايكرو واط/سم²على الجهاز التتاسلي الذكري }
\end{aligned}
$$

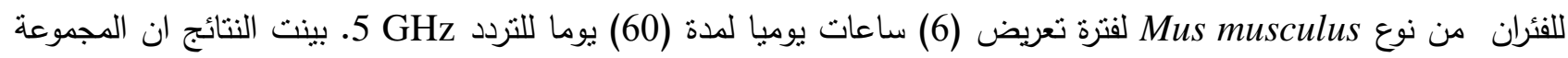

$$
\begin{aligned}
& \text { المعرضة لجرعة اثعاعية } 100 \text { مايكرو واط/سم² اظهرت انخفاضا ملحوظا (P<0.05) في عدد خلايا النطف فضلا عن حصول } \\
& \text { انخفاض معنوي في عدد الخلايا الحية والطبيعية، بينما بينت هذه النتائج حصول زيادة معنوية في عدد الخلايا الميتة والمشوهة. }
\end{aligned}
$$

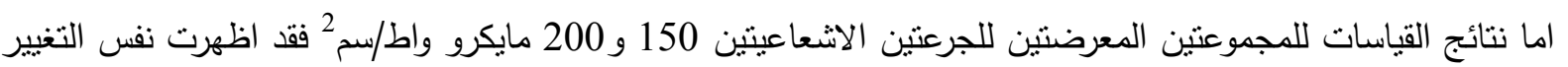

$$
\begin{aligned}
& \text { الذي حدث في المجموعة الاولى. موجات المايكرويف الاشعاعية عند التردد GHz } 5 \text { لها تاثيرات خطرة فسلجيا ونسيجيا للجهاز }
\end{aligned}
$$

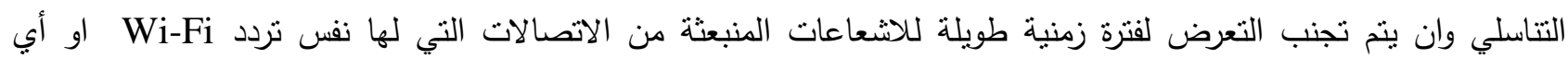

$$
\begin{aligned}
& \text { اتصالات عبر الانترنت. }
\end{aligned}
$$

\section{INTRODUCTION}

The exposure of humans to the electromagnetic radiation (EMR) at very low frequencies between 50-60 hertz continuously, may cause harmful effects on fertility and reproduction (WHO, 1987). There is no strict indication that refers to exposure to extremely low frequency (ELF) which have an effect on revolution and reproduction of mammals. The noticeable effect could be due to the heat produced as a result of exposure to the ELF (AGNIR, 2001). It is well known that male fertility is sensitive and rapidly affected by heat. Studies conducted on experimental animals proved 
the same effects when they were exposed to ELF fields at certain heat levels. Because of the sensitivity of the testis to heat, concern has been directed to the effects of ELF in gonadal functions. In 59 weeks, it led to testicular degeneration at $40 \%$ of the exposed animals and $8 \%$ in contrast to the control ones (Adair, 2000). Researches refered to the effects of exposure to electromagnetic radiation ELF on the number of sperms and their nature. As it recorded a significant decrease in the number of the sperms of mice epididymis associated with significant increase in the percentage of abnormal sperms, when the rats were exposed to frequency $9.45 \mathrm{GHz}$ with a specific absorption rate $1.2 \mathrm{Watt} / \mathrm{kg}$ for a long period (Akdag et al., 1999). There were a decrease in the sperm tubule diameters in rat testis exposed to frequencies between $890-915 \mathrm{GHz}$ for a month (Dasdag et al.,1999) This was proven by(Hong et al.,2003), they recorded a decrease in number and sperm mobility of exposed rats to $50 \mathrm{~Hz}$ for two weeks' time. There was also a decrease in the average of testis weight of the exposed rats to the same frequency for four weeks duration. In the case of ELF effect on man exposed to this field in terms of fertility and reproduction, the study performed by (Lancranjan et al.,1975) showed that the exposure of 21 men to microwave radiation at 3.6 -10.0 $\mathrm{GHz}$ during their work for 1-17 years. About $74 \%$ of them showed changes in sperm production such as the decrease in sperm number and motile sperm number and the natural ones as well. But they did not refer to any difference in 17- ketosteroids level in comparison with the control. They noticed Azoospermia in men exposed for 14 years. A survey was carried out among the Danish soldiers working in mobile ground - air projectile units which uses radar systems, they found that the average density of sperms was very low compared with the control and this was supported by the previous studies (Hjollund et al., 1997). This was also proven by the investigation of (Mikolojczyk et $a l ., 1976$ ), that there was no significant differences in the weight of testis, prostate, adrenal gland pituitary gland and thyroid gland in rats exposed to $2.9 \mathrm{GHz}$, with power density of $10 \mathrm{~m} \mathrm{~W} / \mathrm{cm} 2$ for 6 weeks. Therefore, this research aimed to study the effect of ELF radiation at doses 100,150 and 200 microwatt/cm2 on exposed testes of mice for 60 days at 6 hours daily to 5 $\mathrm{GHz}$.

\section{MATERIALS AND METHODS}

White mice were used in this study Mus musculus Blub/c which range between 2-3 months of age and $23-30 \mathrm{gm}$ of weight. Healthy mice was obtained from the college of veterinary in Mosul University and were kept in plastic cages supplied with plastic metal lids $(20 \times 30 \times 15 \mathrm{~cm}$ dimensions). Steps were taken to ensure good hygiene. Both the control (sham exposure) and the microwave radiation exposure groups. Ambient temperature and humidity throughout the experiment were maintained at $26 \mathrm{C}^{0} . \pm 2$ and $35 \% \pm 5 \%$, respectively, and changing the sawdust weekly. Feeding mixture which consist of $35 \%$ wheat, $34 \%$ corn $20 \%$ soybean, $10 \%$ protein and $1 \%$ dried milk. They were also supplied with water along the time of experimentation (Al-Janaby, 2008).

\subsection{Work System}

The system is made of source of generating microwaves aimed at the mice with $5 \mathrm{GHz}$ frequency, with different power density in microwatt units $/ \mathrm{cm}^{2}$. The instrument were connected to the internet with six hours exposure daily, it is known that the power density is provided from a change of software program due to power of device with computer from internet which represent power supply as shown in Fig. (1). The power meter was used to determine the power density using the job radiation power density level meter microwave. This instrument was used to measure the density power of electromagnetic waves in $\mathrm{W} / \mathrm{m}^{2}$ units. This instrument revealed the radiation dose levels of electromagnetic radiation waves within the microwave frequencies used in telecommunication which include blue tooth, Wi- Fi, electricity generating station, fixed towers of mobile phone and energy towers rather than the measurement of radiation dose released from television and computer screen and video display units (VDU). Also this instrument was able to 
measure the intensity of sound waves associated with high frequency waves in $\mathrm{dB}$ units with positive or negative levels as shown in Fig. (2) (Cornet, 2012). This instrument has another function such as the measurement of intensity of electrical field in $\mathrm{E}(\mathrm{V} / \mathrm{m})$ units, when the instrument was placed closer to the source of generating the electromagnetic radiation waves rather than the ability to draw a figure showing the relationship between power density and sound waves intensity of the same frequency at a certain point between the detector and the source. The detector have other uses such as the power density of radiation dose of the microwave released from the other environment as a type of radiation contamination and also to discover the radiation leak from microwave ovens.

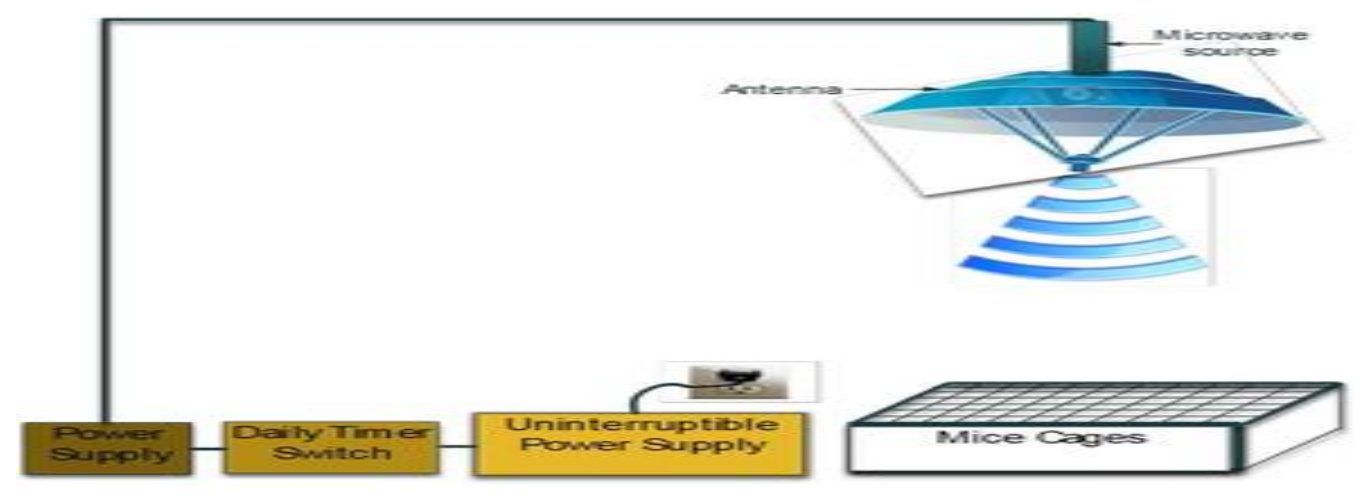

Fig. 1. Work set up

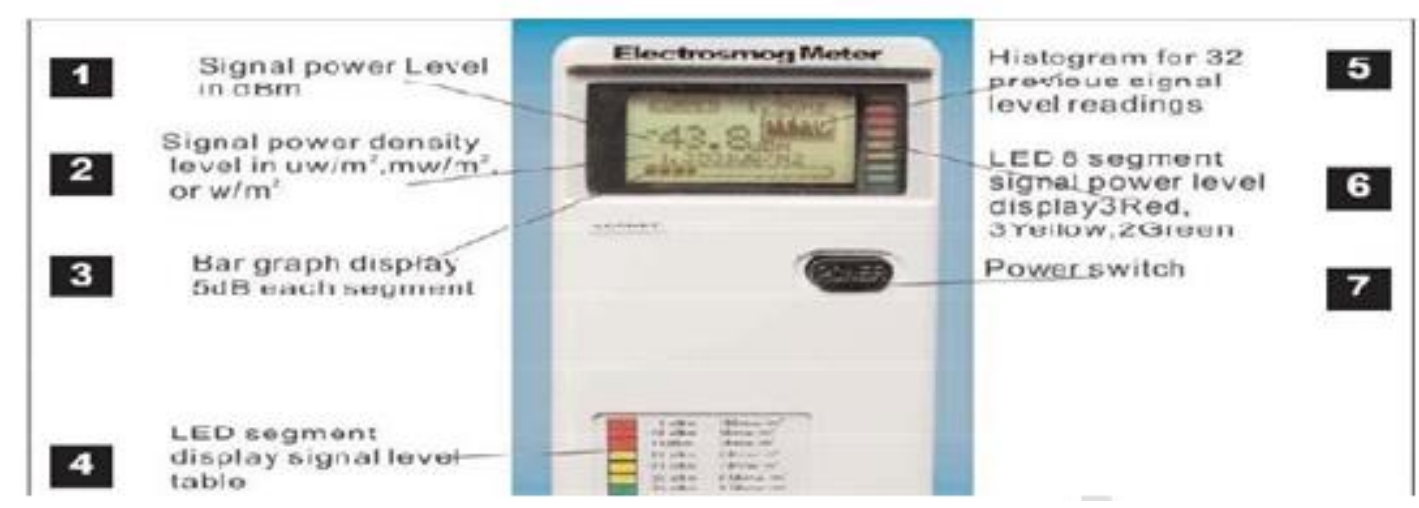

Fig. 2: Electrosmog power meter (Cornet, 2012)

\subsection{Study of Sperm Density and Percentage of Dead and Abnormal Sperms}

Animals were anesthetized using ether after irradiation, then they were dissected and the testis and epididymis were taken out. The semen was extracted from the epididymis (Hassan et al.,1988) by squeezing the contents of the epididymis tail after dissecting them in a clean watch glasses as contianer, then the following test were applied:

\section{Sperm concentrations:}

The percentage of living and dead sperm were assessed and also the percentage of abnormal sperm according to (Sorensen, 1979) method.

\section{Experimental design}


Twenty mice were used in the experiment, they were divided and given the chosen doses as follow:

1- First group (control) include 5 male mice not exposed to the electromagnetic radiation field (control). Second group include 5 mice they were exposed to $100 \mu \mathrm{W} / \mathrm{cm}^{2}$

2- Third group include 5 mice and exposed to $150 \mu \mathrm{W} / \mathrm{cm}^{2}$

3 - Fourth group include 5 mice exposed to $200 \mu \mathrm{W} / \mathrm{cm} 2$

4- Group (2-4), the number of male mice are 15 used for 60 days at a rate of 6 hours daily. The work system was prepared at $5 \mathrm{GHz}$ frequency as in Fig. (1) with different exposure of power density (100, 150 and $200 \mu \mathrm{W} / \mathrm{cm} 2$ ) on white male mice for 60 days and at period 6 hours daily.

\subsection{Statistical Analysis}

One way analysis of (ANOVA) after variance was used in this experiment. Differences were determined by Duncan Include significant level was determined at $\mathrm{p} \leq 0.05$ (Steel and Torrie, 1980).

All results were included in (Table 1).

\section{RESULTS}

Table 1: All results with mean value, significant value and standard division Measurement

\begin{tabular}{|c|c|c|c|c|c|}
\hline $\begin{array}{l}\text { Percentage } \\
\text { of abnormal } \\
\text { sperm cells }\end{array}$ & $\begin{array}{l}\text { Percentage } \\
\text { of normal } \\
\text { sperm cells }\end{array}$ & $\begin{array}{l}\text { Percentage } \\
\text { of dead } \\
\text { sperm cells }\end{array}$ & $\begin{array}{l}\text { Percentage } \\
\text { of living } \\
\text { sperm cells }\end{array}$ & $\begin{array}{l}\text { No of sperm } \\
\text { cells in } \\
\text { epididymis }\end{array}$ & \\
\hline $13.44 \mathrm{~d} \pm 0.73$ & $86.66 a \pm 0.83$ & $12.19 \mathrm{~d} \pm 0.81$ & 87.81 at0.82 & $28.96 a \pm 0.99$ & Control \\
\hline $55.03 \mathrm{c} \pm 0.55$ & $44.97 b \pm 0.55$ & $53.96 c \pm 0.43$ & $46.05 b \pm 0.44$ & $15.60 \mathrm{~b} \pm 0.49$ & $100 \mu \mathrm{W} / \mathrm{cm} 2$ \\
\hline $65.28 \mathrm{~b} \pm 0.46$ & $34.93 \div 0.72$ & $64.23 b \pm 0.52$ & $35.90 \mathrm{c} \pm 0.69$ & $11.86 \mathrm{c} 0.23$ & $150 \mu \mathrm{W} / \mathrm{cm} 2$ \\
\hline 76.33 at 0.45 & $23.68 \mathrm{~d} \pm 0.45$ & $75.28 \mathrm{a} \pm 0.21$ & $24.72 \mathrm{~d} \pm 0.21$ & $6.88 \mathrm{~d} \pm 0.26$ & $200 \mu \mathrm{W} / \mathrm{cm} 2$ \\
\hline
\end{tabular}

3.1 No of Sperm Cells in Epididymis

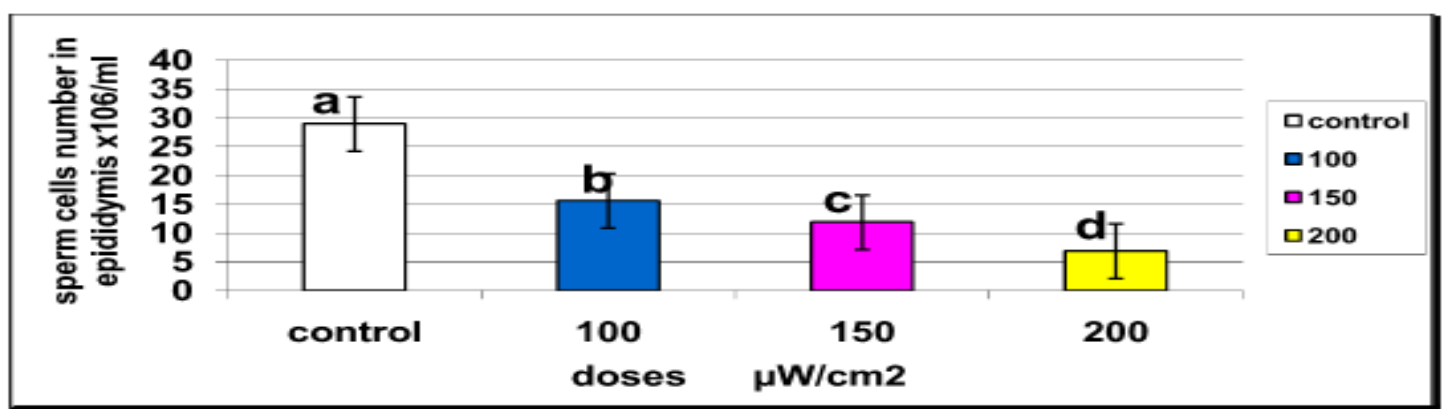

Fig. 3: Show the effect of microwave radiation 100,150 and $200 \mu W / \mathrm{cm} 2$ for 6 hours daily exposure to $5 \mathrm{GHz}$ for 60 days on no of sperm cells in epididymis with Standard error mean. 
3.2 Percentage of Living Sperm Cells

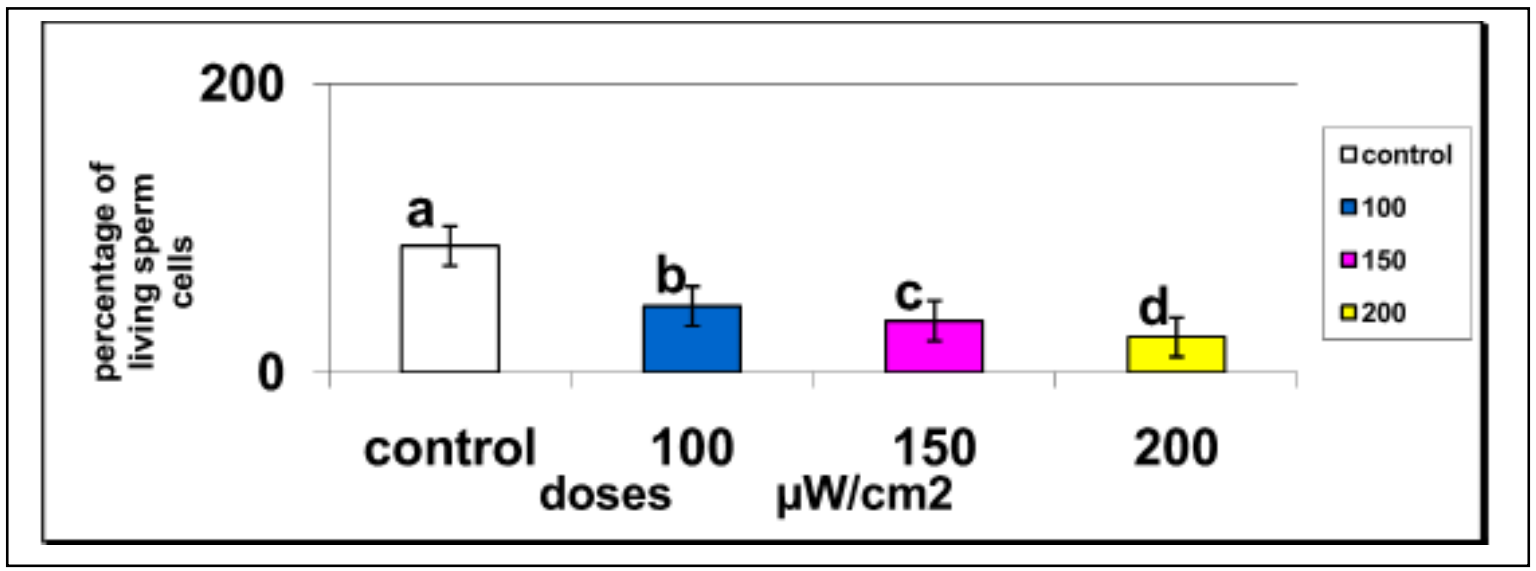

Fig. 4:The effect of microwave radiation at a dose of 100,150 and $200 \mu \mathrm{W} / \mathrm{cm} 2$ for 6 hours dailybasis at $5 \mathrm{GHz}$ for 60 days on the percentage of living sperm cells Standard error mean

3.3 Percentage of Dead Sperm Cells

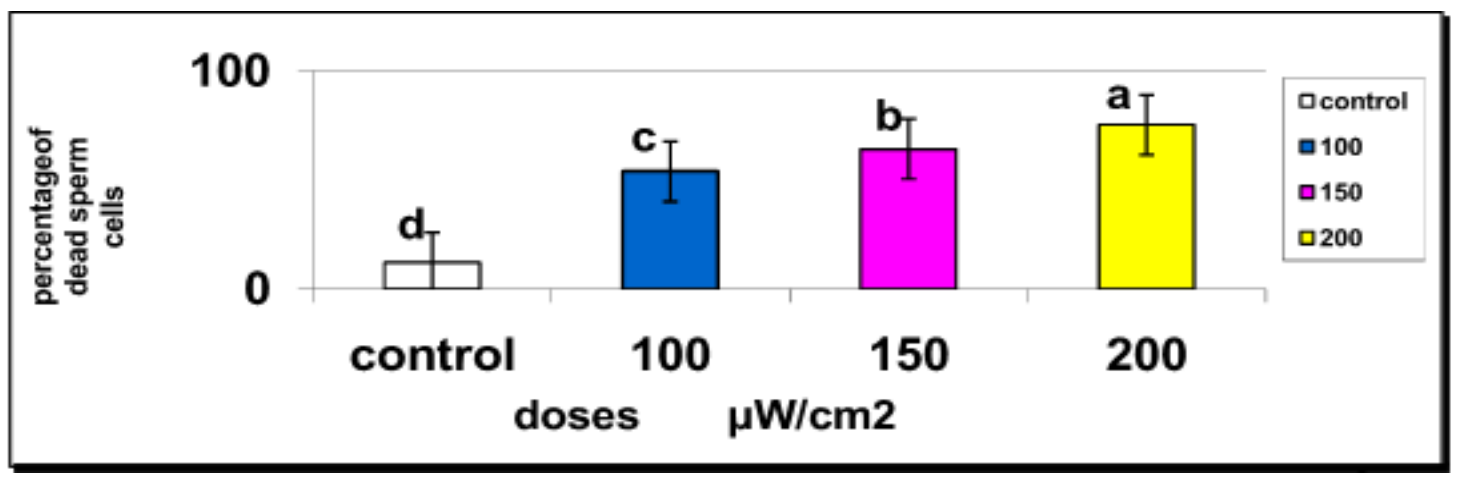

Fig. 5: The effect of microwave radiation at the doses 100,150 and $200 \mu W / \mathrm{cm} 2$ at 6 hours on daily basis at $5 \mathrm{GHz}$ on a period of 60 days on the percentage of dead sperm cells standard error mean

\subsection{Percentage of Normal Sperm Cells}

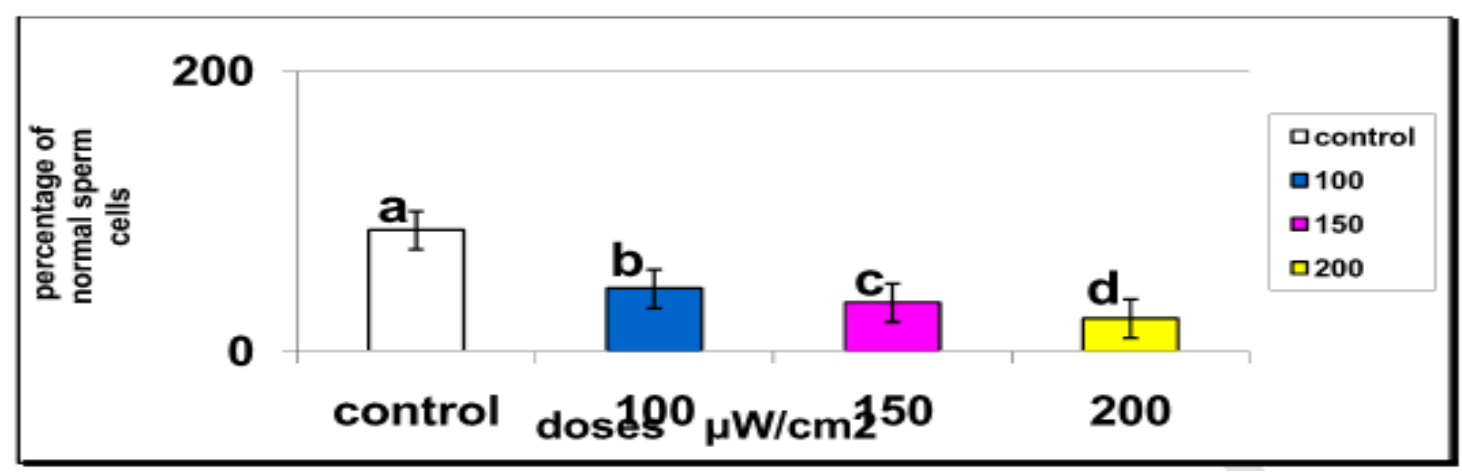

Fig. 6: The effect of microwave radiation at 100, 150 and $200 \mu W / \mathrm{cm} 2$ doses for 60 days at 6 hours daily with $5 \mathrm{GHz}$ on the percentage of normal sperm cells Standard error mean 
3.5 Percentage of Abnormal Sperm Cells

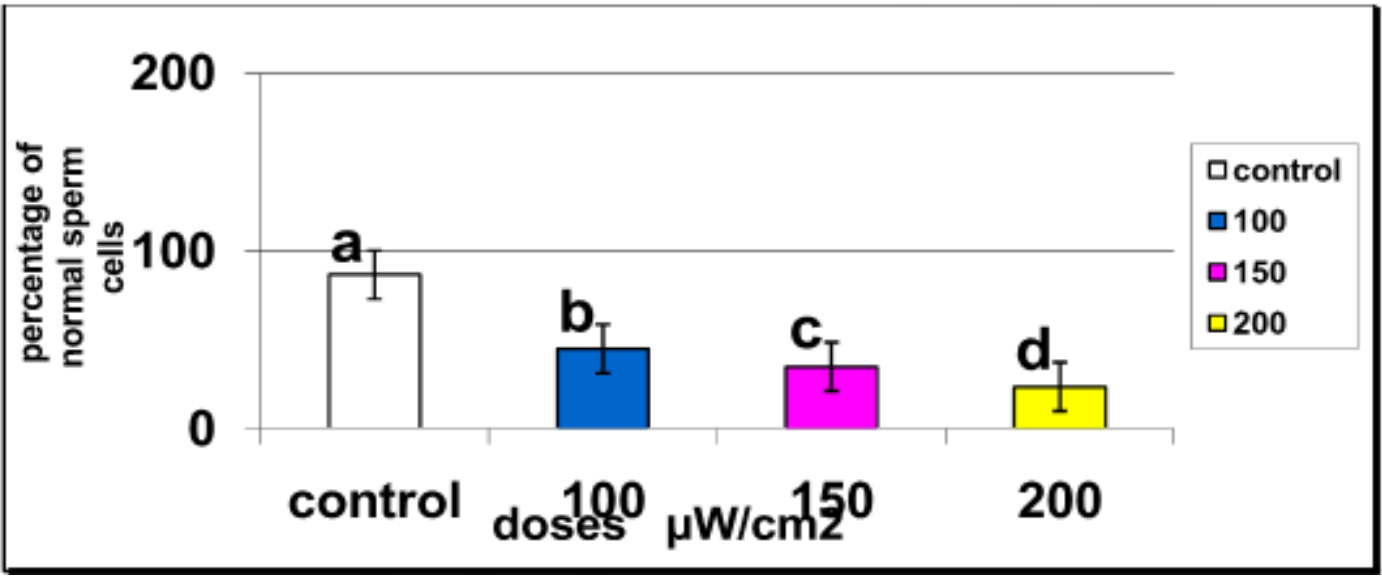

Fig. 7: The effect of microwave radiation at the doses of 100,150 and $200 \mu W / \mathrm{cm} 2$ and for 60 days at 6 hours daily with $5 \mathrm{GHz}$ on the percentage of abnormal sperm cells

3.6 Histological Changes of Testis

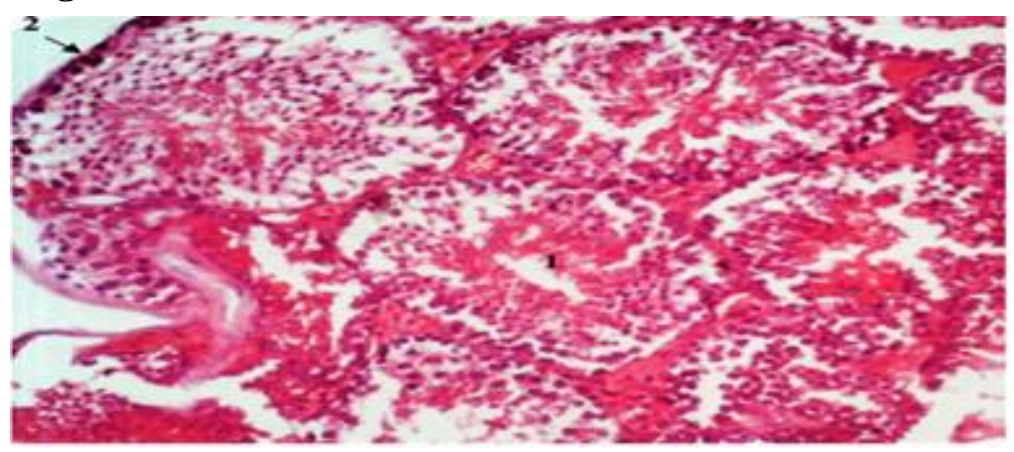

Fig. 8: C.S in testis of control group showing 1- seminiferous tubules 2- testis capsule. stain H\&E. 10X

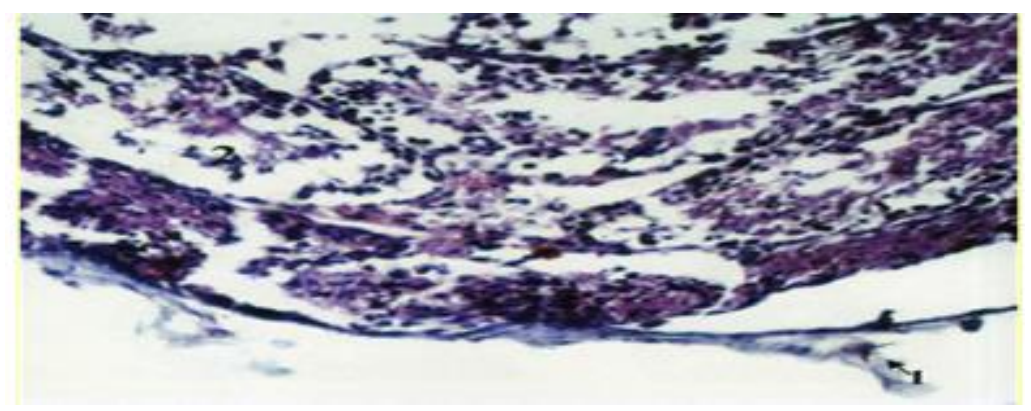

Fig. 9: C.S in testis of mice exposed to $100 \mu \mathrm{W} / \mathrm{cm} 2$ showing 1 -speration of testis capsule 2necrosis in seminiferous tubules. Stain H\&E.10X 


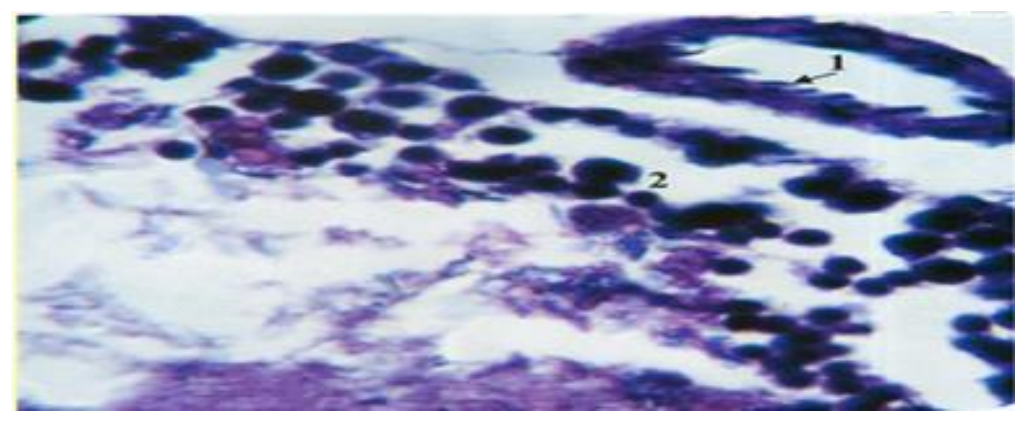

Fig. 10: C.S in seminiferous tubules of mice exposed to $150 \mu \mathrm{W} / \mathrm{cm} 2$ showing 1- Magnifical of nucleus cells of blood vessels 2-Necrosis in seminiferous tubules .Coating H\&E.40X

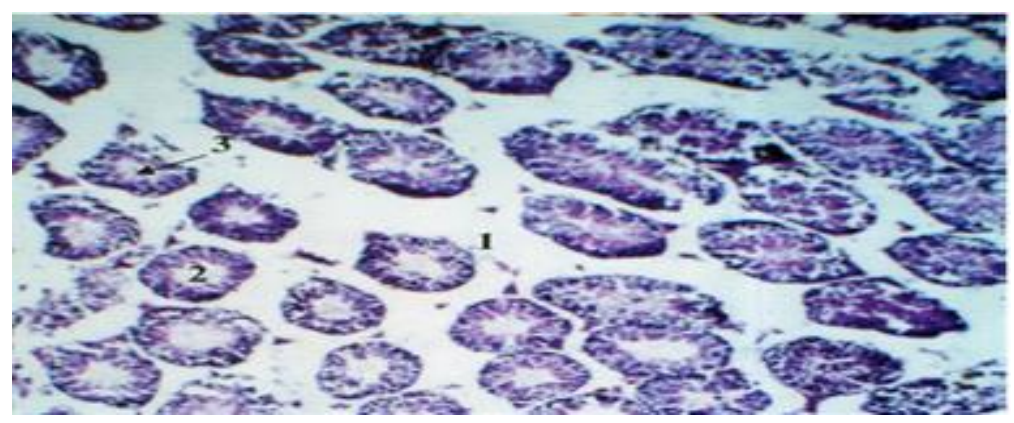

Fig. 11:C.S in seminiferous tubules of mice which exposed to $200 \mu \mathrm{W} / \mathrm{cm} 2$ showing 1 - Necrosis of arulear connective tissue 2- appearances of vacuoles of star shape in seminiferous tubules.3-contraction of same seminiferous tubules in mice stain H\&E. 10X

\section{DISCUSSION}

In Fig. (3) there was a significant decrease at $(p<0.05)$ in the number of sperm cells in epididymis of the mice exposed to microwave radiation at $5 \mathrm{GHz}$ for 6 hours daily for 60 days when the 100, 150 and 200 microwatt $/ \mathrm{cm} 2$ dose were used, compared with the control treatment. This comes in agreement with (Singh and Behari, 2005) who studied the effects of electromagnetic radiation fields at $50 \mathrm{GHz}$ on the number of sperm cells in epididymis, weight of testis and secondary sexual organs in male mice. They found a significant decrease in the number of sperm cells in epididymis and a decrease in the number of sperm cells in the semen tubules in rats exposed for 1 or 2 hours. Another study carried out by (Kim et al., 2007) showed the effect of electromagnetic field at $2.45 \mathrm{GHz}$ in germ cell spermatogenesis of male rats which were exposed for 1-2 hours/day for 8 weeks, the quantitative analysis of leydig cells in the testis show significant increase of sexual hormone in serum (testosterone). Also there was a significant decrease in the number of spermatocytes in the semen tubules of the exposed rats in comparison with the control. (Salama et al., 2010) found that the exposure of rabbits to EMR fluctuated frequencies at low intensity led to a significant decrease in semens tube diameter. The study done by (Falzone et al., 2010) found that the continuous exposure to the electromagnetic field at very low frequencies lead to programmed killing of semen cells in rats of Balb/c strain. Whereas no significant effect was found on body weight and testicular organs. These results refers to possibility of programmed cell killing of the spermatogenetic cells, in mice because of the continuous exposure to the EMR frequencies at $60 \mathrm{~Hz}$ (Kim et al., 2009). The World health organization (WHO, 2005) warns from the over exposure to electromagnetic fields which would lead to destroy the sperms. This will amount to strong decrease in sperm speed of these persons, in comparison to those who have 
moderate exposure. The change in semens quality of those who are over - exposed to electromagnetic fields is due to the effect of radiation which cause a severe injury on the nucleic acid which in turn have an effect on the testis cells that produce the testosterone hormone, or the tubes producing the semens. Wdowiak et al.,(2007) concluded through his research by exposing both mice testis to the waves of the mobile phone at $900 \mathrm{MHz}$ which caused a decrease in their fertility by causing a trophy of testis tubules. Yan et al.,(2007) emphasized that the waves released from the mobile phone caused a significant decrease in the number of sperms in mice. Figs (4-6) show a significant decrease at $(\mathrm{p}<0.05)$ in the percentage of living and normal sperm cells through the exposure to microwave radiation at $5 \mathrm{GHz}$ frequency for 6 hours along a period of 45 days at the doses 100, 150 and 200 microwatt $/ \mathrm{cm}^{2}$. While the percentage of dead and abnormal sperm cells shown in Figs $(5-7)$ an increase was noticed at $(\mathrm{p}<0.05)$ when they were exposed to the same treatment before. Figs (3-7) present the following information: - Values expressed by average \pm experimental error - The different letters on each rectangular means significant differences at less than $0.05 \%$ level.- Number of animals is 5 per group. This is in agreement with AL-hakeem (2006), the results of study revealed that the radio electromagnetic field with short wave at three frequencies $(1.6,2.4,3.2) \mathrm{MHz}$ at power density 16 millwatt $/ \mathrm{cm}^{2}$ have harmful effects on sperm formation and testis functions as there was a decrease noticed in sperm cells number at the head of epididymis and an increase in the percentage of the dead and abnormal sperm cells in the tail of epididymis as compared with a decrease in the percentage of living sperm cells. This results was in agreement with that of (Akdag et al., 1999), the exposure of rats to the radio electromagnetic field at $9.45 \mathrm{GHz}$ caused a decrease in the number of sperm cells in the epididymis and an increase in dead sperm cells percentage. There was a negative effect on the sexual efficiency of the exposed person to frequencies between 3.6-10 GHz. They recorded a decrease in the number of sperm cells motile and and other abnormalities led to changes in the functions of sperms (obtained normal sperm cells. Also there were no sperm cells formed in the persons who are exposed for 14 years (Lancranian et al., 1975). Hjollund et al., (1997) showed that there was a significant reduction in the average density of sperm cells found in the soldiers exposed to the radar waves. This was in agreement with Atasoy et al.,(2012) who found that the mobile phone waves when used at 2 hours daily for 45 days imposed on rats 70 days ago. Abnormalities in sperms at the head, neck and tail, rather than loss in testis weight and number of living sperms fertility hormones and eventually affect the average of reproduction in men and also affect the speed, the number, and the number of abnormalities occurred in sperms (Hamada et al., 2011). These harmful effects which resulted from radio electromagnetic field was owing to the thermal load or to the oxidative stress or to the direct effect on endocrine glands. The studies proved that thermal or heat sensitivity of testis tissue in mammals resulted from exposure to different frequencies, (Pucak et al., 1977). In 1980 another study conducted by Cairnie and leach concerning the effect of heat or temperature on testis through exposing mice to a water bath at $32-43{ }^{\circ} \mathrm{C}$. for 4 hours, when they discovered a damage in testis tissue after two hours of exposure to the water bath at $41^{\circ} \mathrm{C}$ for 30 minutes at $43{ }^{\circ} \mathrm{C}$ which caused lowering in sperm number in the epididymis after 30 minutes exposure. There was a similarity between the results caused by the radio electromagnetic field and that caused by heat on testis (Lebovitz and Johnson, 1987). Absorption of energy of the electromagnetic field by the body led to raise the testis temperatures and the sperm production in mammal's decreases when exposed to temperature a bit higher than the normal temperature of the body. The heat generated through exposure to electromagnetic field causes such effects in testis functions similar to those effects resulted from high temperature (Leonard et al., 1983). The mice exposed to $2.45 \mathrm{GHz}$ showed an increase in temperature which resulted in exhaustion of primary spermatocyctes (Saunders and Kowalczuk, 1981), with increase in percentages of sperm abnormalities and reduction of fertilization in mice exposed to active free radicals affect the lipid and protein layer in the plasma membrane of the sperm rather than changes in the DNA. Since sperms contain lipid materials such as unsaturated multi fatty acid, plasmalogen and sphingomyelins which are susceptible to oxidation 
causing disturbances in the function of sperm (Sanocka and Kurpisz, 2004; Esterbauer et al., 1990). The free radicals are playing their harmful role on phosphor - lipids found in cell membrane leading to formation of malondialdehyde (Halliwelland Gutteridge, 1984). It is possible to predict lipids peroxidation by measurement of malondialdehyde (Yucel et al., 1998). A lipid peroxidation is considered as essential key for the active oxygen types leading to lose the ability for fertilization as a results of the lack of sperms and a quick loss of energy inside the cell leading to destroy and decrease of sperm activity and increase of abnormal sperms (De Lamirande and Gangon,1992), These changes may be due to the interaction of active oxygen varieties formed as a result of the exposure to electromagnetic field together with energy production and metabolism in sperms leading to lowering the concentration of ATP in the sperms and eventually the loss of sperms and death (Griveau et al.,1995). Another study by Sanders et al.,(1984) showed that the exposure to the electromagnetic field caused lowering of energy sources such as ATP. It is well known the formation of sperms need a high energy, mobility and their ability for fertilization. The power houses physiologically provide the sperms by energy through glucose and fructose metabolism since the fructose is available in the semen of rats and metabolized and only $10 \%$ of the metabolites will be converted to glucose (Burant and Davidson, 1994). The active energy varieties are poisonous to cells and tissue, as they cause histological pathogenic changes in body cells and tissues including testis cells (Ishihara et al., 2000).

\section{Histological Changes of Testis}

The changes observed had an effect on the structure of the testis tissue such as degeneration changes in semen tubules represented by necrosis and sloughing of sperm generating cells and sertoli cells, in some semen tubules especially those located under the semen sac. These changes retard the formation and maturation of sperms and eventually increase the percentage of dead sperms and abnormality. Knowing that sertoli cells participate in the formation of sperms and their maturation and at the end they cause an interference of sperm maturation and other changes represented by degeneration tissue. This was in agreement with Sanocka and Kurpisz (2004) they used different frequencies on the testis tissue. They showed that these degeneration raised up the temperature due to the exposure to radio electromagnetic field. The reason of for these changes may be due to the effect of radio electromagnetic field in the role or function of mitochondria and through disturbance in energy production ATP. The effect on sodium pump and plasma membrane or through lowering of $\mathrm{pH}$ of cells by the increase of lactic acid which cause a reduction in protein synthesis and retarding the formation of plasma membrane which means the occurrence of necrosis (Al-Zobeer, 2003).

\section{CONCLUSION}

The $5 \mathrm{GHz}$ of microwave radiation has harmful physiological and histopathological effects on reproductive system. Avoid exposure for a long time to radiation from communication gadgets that have the same frequency as $\mathrm{Wi}-\mathrm{Fi}$ communication or any communication from internet will help a lot.

\section{REFERENCES}

Al-Akhras, M.A.; Elbetieha, A.; Hasan, M.K.; Al-Omari, I.; Darmani, H.; Albiss, B. (2001). Effects of extremely low frequency magnetic fields in adult male and female rats. Bioelectromagnetics, 22,340-344.

Adair, R.K. (2000). Static and Low - Frequency Magnatic Field Effects: Health Risks and Therapies. Rep. Prog. Phy., 63,415-454.

AGNIR, (2001). Possible health effects from terrestrial trunked radio (TETRA). Report of an Advisory group on non-ionizing radiation. Doc. NRPB. 12(2), 1-86. 
Al-Hakeem, A.A. (2006). Study. The effect of electromagnetic waves which has short wave length in some physiological factors in rats. PHD philosophy Thesis. Veterinary Medicine College. Mosul University. $128 \mathrm{p}$.

Al-Janaby, K.A. (2008). The effect of aqueous extract of grassed on oxidative stress induced by hydrogen peroxide in male rat. Msc. Thesis. Tikrit University, IRAQ. 65 p.

Akdag, M.Z.; Celik, M.S.; Ketani, A.; Nergiz, Y.; Deniz, M.; Dasdag, S.(1999). Effect of chronic lowintensity microwave radiation on sperm count, sperm morphology, and testicular and epididymal tissues of rats. Electro- and Magnet. Biol., 18, 133-145.

Atasoy, H.I.; Gunal M.Y.; Atasoy, P.; Elgun, S.; Bugdayci, G.(2012). Immunohistopathologic demonsttation of deleterious effects on growing rat testes of radiofrequency waves emitted from conventional Wi-Fi devices.; http://www.ncbi.nlm.nih.gov/pubrned/2246 5825 .

Al-Zobeer, C.A. (2003). Effect sodium degeneration on testis function in rats which exposed to oxidative stress with hydrogen peroxide. Msc letter. Medicine College. Veterinary Mosul University.

Burant, C.F.; Davidson, N.O. (1994). GLUT3 glucose transporter isoform in rat testes: localization effect of diabetes mellitus and comparison to luman testes. Am. J. Physiol. 36, 1488-1495.

Cornet, (2012). Microsystem lnc., ED85EXS rev.1400 Coleman Ave \#C28, Santa Clara, CA 95050 USA.; www.cornetmicro.com.

Dasdag, S.; Ketani, M.A.; Akdag, Z.; Ersay, A.R.; Sari, I.; Demirtas, O.C.; Celik, M.S.(1999). Wholebody microwave exposure emitted by cellular phones and testicular function of rats. Urol. Res., 27, 219-223.

De Lamirande, E.; Gangon, C. (1992). Reactive oxygen species and human spermatozoa. I. Effects on the motility of intact spermatozoa and on sperm axonemes, and II. Depletion of a denosine triphosphate plays an important role in the inhibition of sperm motility. J. Androl.,13, 368-386.

De Vita, R.; Cavallo, D.; Raganella, L.; Eleuter, P.; Grollion, M.G.; Calugi, A. (1995). Effects of 50Hz magnetic fields on mouse spermatogenesis monitored by flow cytometric analysis. Bioelectromagnetics. 16, 330-334.

Esterbauer, H.; Rotheneder-Dieber, M.; Waey, G.; Stiregl, G.; Jurgens, G. (1990). Biochemical, Structural and functional properties of oxidized low density lipoprotein. Chem. Res. Toxicol., 3, 77-92.

Falzone, N.; Huyser, C.; Franken, D.R.; Leszczynski, D. (2010). Mobile Phone Radiation Dose not Induce Pro-Apoptosis Effect in human Spermatozoo. Radiat. Res., 174,169-176.

Griveau, J.F.; Dumont, E.; Renard, P.; Callegari, J.; Lelannou, D. (2010). Reactive oxygen species, lipid peroxidation and enzymatic defense system in human spermatozoa. J. Reprod. Fert.,103, 17-26.

Halliwell, B.; Gutteridge, J.M.C.(1984). Lipid peroxidation, oxygen radicals, cell damage and antioxidant therapy. Lancet., 1, 1396-1397.

Hamada, J.A.; Singh, A.; Agarwal A. (2011).Cell Phone and their Impact on Male Fertility : Fact or Fiction. Center for Reproductive Medicine, Cleveland Clinic, Cleveland.Ohio. U.S.A.

Hassan, A.B.; Ayoub, M.M.; Doghaim, R.F.; Yousef, H.L.; Eid, M.A. (1988). Studies of the effect of some antihistamines on the reproductive organs of male rats. Vet. Med. J., 31(2) 277-286.

Hjollund, N.H., Bonde, J.P.; Skotte, J. (1997). Semen analysis of personnel operating military radar equipment. Repord. Toxicol., 11(6) 897p.

Hong, R.; Liu, Y.; Yu, Y.M.; Hu, K.; Weng, F.Q. (2003). Effects of extremely low frequency ectromagnetic fields on male reproduction in mice. Zhonghua. Lao. Dong. Wei. Sheng. Zhi. Ye. Bing .Za .Zhi., 21(5), 342-345.

Ishihara, M.; Itoh, M.; Miyamoto, K.; Suna, S.; Takeuchi, Y.; Takenaka, I.; Jitsunari, F.(2000). permatogenic disturbance induced by di-(2- ethylhexyl)phthalate is significantly prevented by treatment with antioxidant vitamins in the rat. Int. J. Androl., 23, 85-94.

Kim, Y.; Hyun, T.K.; Ki, H.M.; Hyoun, J.S. (2007). "Long-Term Exposure of Rats to a $2.45 \mathrm{GHz}$ Electromagnetic Field: Effect on Reproductive Function". Institute of Biomedical Engineering, Yeungnam University, Daegu, Korea. 
Kim, Y.W.; Kim, H.S.; Lee, J.S.; Kim, Y.J.; Lee, S.K.; Seo, J.N.; Jung, K.C.; Kim, N.; Gimm, Y.M., (2009). Effects of $60 \mathrm{~Hz} 14 \mathrm{~T}$ micromagnetic field on the apotosis of testicular grem cell in mice. Bioelectromagnetics. 30(1), 66-72.

Lancranjan, I.; Maicanescu, M.; Rafaila, E.; Klepsch, I.; Popescu, H.I. (1975). Gonadic function in workmen with long-term exposure to microwaves. Health phys. 29, 381-383.

Lebovitz, R.M.; Johnson, L.(1987). Acute, Whole body microwave exposure and testicular function of rats. Bioelectromagnetics, 8, 37-46.

Leonard, A.; Berteaud, A.J.; Bruyere, X. (1983). An evaluation of the mutagenic,carcinogenic and teratogenic potential of microwave. Mutation Res., 123, 31-46.

Mikolojczyk, H.J. (1976). Microwave-induced shifts of C.C. and Shore, M. Ceds Biological effects of electromagnetic wave, Vol. I. U.S. Department of Health Education and Welfare, HEW publication (FDA).; 7(80180), 377-382.

Pucak, G.J.; Lee, C.S.; Zaino, A.S. (1977). Effects of prolonged high temperatures on testicular development and fertility in the male rat. Lab. Anim. Sci., 27(1), 76- 77.

Salama, N.; Kishimoto, T.; Kanayama, H.O. (2010). Effects of exposure to a mobile phone on testicular function and structure in aduit rabbit. Int. J. Androl, 33,88-94.

Sanocka, D.; Kurpisz, M. (2004). Reactive oxygen species and sperm cell. Reprod. Biol. and Endocrinol., 2,12 p.

Sanders, A.P.; Joines, W.T.; Allis, J.W. (1984). Effects of continuous wave, pulsed, and sinusoidal amplitude - modulated microwaves on brain energy metabolism. Bioelectromagnetics, 6,86-97.

Saunders, R.D.; Kowalczuk, C.L. (1981). Effects of $2.45 \mathrm{GHz}$ microwave radiation and heat on mouse spermatogenic epithelium Int. J. Radiat. Biol., 40, 623-632.

Singh, Y.; Behari, J. (2005)."The Effect of Whole Body Exposure of $50 \mathrm{GHz}$ Microwave Radiation on Sperm Counts in Rats School of Environmental Sciences." Jawaharlal Nehru University, New Delhi, India.; www.htcampus.com/.../schoolenvironmental- sciences-jawaharlal.

Sorensen, A.M. (1979). "Animal Reproduction Principle and Practice". McGraw-Hill Book Company Baltimore, pp. 428-431.

Steel, R.G.D.; Torrie, J.H.(1980). "Principle and Procedures of Statics". $2^{\text {nd }}$ ed.. New York: McGrawHillbook company, Inc., pp. 78-80,107-109,123-127.

Wdowiak, A.; Wdowiak, L.; Wlktor, H.(2007). Enhancement of Lipid peroxidation in the liverof mice exposed to magnetic fields. Industrial Health. 35,285-290.

WHO, (World Health Organization).(1987). Electromagnetic Field and Public Health. http:// www. Who. int.

WHO, (World Health Organization). (2005). Electromagnetic Fields and Public Health. Electromagnetics Hypersensitivity. Fact Sheet No.296.

Yan, J.G.; Agresti, M.; Bruce, T.; Yan, Y.H.; Granlund, A.; Matloub, H.S. (2007). Effect of cellular phone emission on sperm mobility in rats. Fertility and Sterility. 88(4), 957-64.

Yucel, D.; Aydogdo, S.; Cehreli, S.; Saydam, G.; Ganatar, H.; Sense, M.; Topkaya, B.; Nebioglu, S. (1998). Increase oxidant stress in dilated cardiomyopathic heart failure. Clin. Chem., 44, 148- 154. 